Digital Press Social Sciences and Humanities

Implementation of Karmaphala Value in Problem-solving Process of Migrant in Bali

Putu Yoga Sukma Pratama and Ni Made Swasti Wulanyani

Proceeding of The 10th International Conference of Indigenous and Cultural

Psychology 2019

Kwartarini Wahyu Yuniarti, Donald H. Saklofske, Rosnah Ismail, Saadi Lahlou (eds) 


\title{
Implementation of Karmaphala Value in Problem-solving Process of Migrant in Bali
}

\author{
Putu Yoga Sukma Pratama ${ }^{1, *}$ \& Ni Made Swasti Wulanyani ${ }^{2}$ \\ 1 Faculty of Psychology, Universitas Airlangga, Surabaya, Indonesia \\ 2 Psychology Study Program, Faculty of Medicine, Universitas Udayana, Bali, Indonesia \\ *e-mail: putuyoga1409@gmail.com
}

\begin{abstract}
The Balinese culture that is deeply rooted in Shiva-Buddhist tenet shows its uniqueness, which is characteristic of Hinduism in the archipelago. The Balinese culture is preserved together in the form of regulations that are held firmly by each traditional village. One concept of Balinese culture that is often used and held firmly by Balinese society is Karmaphala. Karmaphala is a concept of justice that emphasizes the consequences of past deeds. This concept becomes the Balinese frame of mind in facing a problem in order to be able to resolve these problems wisely. This research was conducted qualitatively to explore how the implementation of the Karmaphala value to Migrant communities living in Bali in solving problems. Data was collected through in-depth interviews, and member checking was done to confirm the credibility of data. The results of this study reveal that the concept of Karmaphala is a passive avoidance solution in solving problems faced by migrant communities through silent behavior, accepting, surrendering, and moving away. This behavior tends to be done in dealing with problems because of the belief in the respondent that the person who made the problem will be exposed to karma from his actions.
\end{abstract}

\section{Keywords}

Bali, karmaphala value, migrant, problem solving

\section{Introduction}

Job availability can be a driving factor for migrants to settle in Bali in the hope of obtaining employment. Based on Labor Planning Data of Bali Province (Department of Labour and Transmigration of Bali Province, 2012), in 2015 there were 2.36 million jobs from various employment statuses; and in the same year, Indonesian migration statistics showed that 428 thousand migrants were living in Bali (Central Bureau of Statistic, 2015). This figure shows that migrants will have high employment opportunities because the number of jobs available is far more than the number of migrants living in Bali. Migrants that decide to settle in Bali required to be able to adapt to the new environment. Adaptation is a step taken to deal with changes in the environment and culture. This shows that if migrants fail to adapt to the new environment because of differences in geography, culture, language, and customs between their origin and the new place of residence, migrants will have difficulty interacting with Balinese people.

The adaptation process carried out by migrants, may cause migrants to be exposed to Balinese cultures that are not yet well known by them, including the concept of Karmaphala. The exposure of migrants to new things on the island of Bali shows one proof of the process of interaction between migrants and Balinese people which can gradually influence the thoughts and actions of migrants or vice versa. The existence of interactions can influence, change, or improve the behavior of other individuals or vice versa (Bonner, 1953). That is, the relationship or process of interaction can affect each other so that it can change the bad to be better or even vice versa. This is what underlies the researchers to see how the implementation of Karmaphala values in Migrant communities, especially during the problem-solving process.

The Karmaphala concept was chosen as the topic of this research because Karmaphala contains the concept of justice that whatever we do must have consequences and it also affects ourselves. The concept was then used as the basis for Balinese thinking in dealing with a problem so that it could be resolved wisely and becomes a ground rule of Hinduism that if every action in life was followed by an unwholesome attitude (adharma), then it will certainly bring bad results too so that optimism will arise 
in every human being that all deeds done will bring results according to what has been done (Munidewi, 2017).

The application of Karmaphala values in this study focused on the context of problem-solving. This is based on the possibility that cultural differences and rules between the origin and overseas areas can trigger problems not only for migrants but also for Balinese people. This is supported by the opinion that religious and traditional values will never run out as a source of conflict and can occur indefinitely (Sarwono, 2005). That is, these problems cannot be solved if there is no problem-solving process involved.

The way to solve the problem will certainly be different depending on the problems faced and also depend on individuals who experience these problems. Each individual will make a different problemsolving process for the same problem or it could be a different problem solved in the same way by each individual. Thus, there is a difference in the process of solving this problem, the researcher wants to know more about how the migrant communities implement Karmaphala values in the process of solving the problem.

Problem-solving is a cognitive process for identifying or finding a variety of potential effective solutions to a particular problem or increasing the possibility of choosing the most effective solution from various alternatives (D'Zurilla \& Goldfried, 1971). In solving social problems, there are two general processes namely problem orientation and problem-solving style (D’Zurilla, Nezu, \& Olivares, 2002). Problem orientation is divided into two parts, namely, positive orientation (constructive) and negative orientation (dysfunctional) to the problem. Based on the problem orientation, it will lead to a different problem-solving style. Individuals with a positive orientation to the problem will have a rational problem-solving style, while impulsive and careless becoming a problem-solving style for individuals who are negatively oriented to the problem. Rational problem solving will lead to positive results, and vice versa, being impulsive, careless, or avoiding will lead to negative results.

The process of solving the problem becomes a cycle, especially for individuals who have positive orientation problems and rational problem-solving styles to find better solutions or to redefine problems with more realistic goals. Unlike individuals with negative orientation problems and poor problemsolving style, they tend to give up easily and do nothing, so that they try to ask others to help solve the problems. Referring to the theory, the problem-solving process illustrated in Fig. 1.

\section{Methods}

This study used qualitative research methods because this research emphasizes the search for meaning, understanding, concepts, and descriptions of a phenomenon. The uniqueness of each individual makes this research method appropriate to understand this uniqueness because the qualitative approach has the assumption that understanding human behavior is not only obtained from the surface behavior but also the inner perspective of human behavior because from here it will get a complete picture of humans and their world (Ghony \& Almanshur, 2012). 


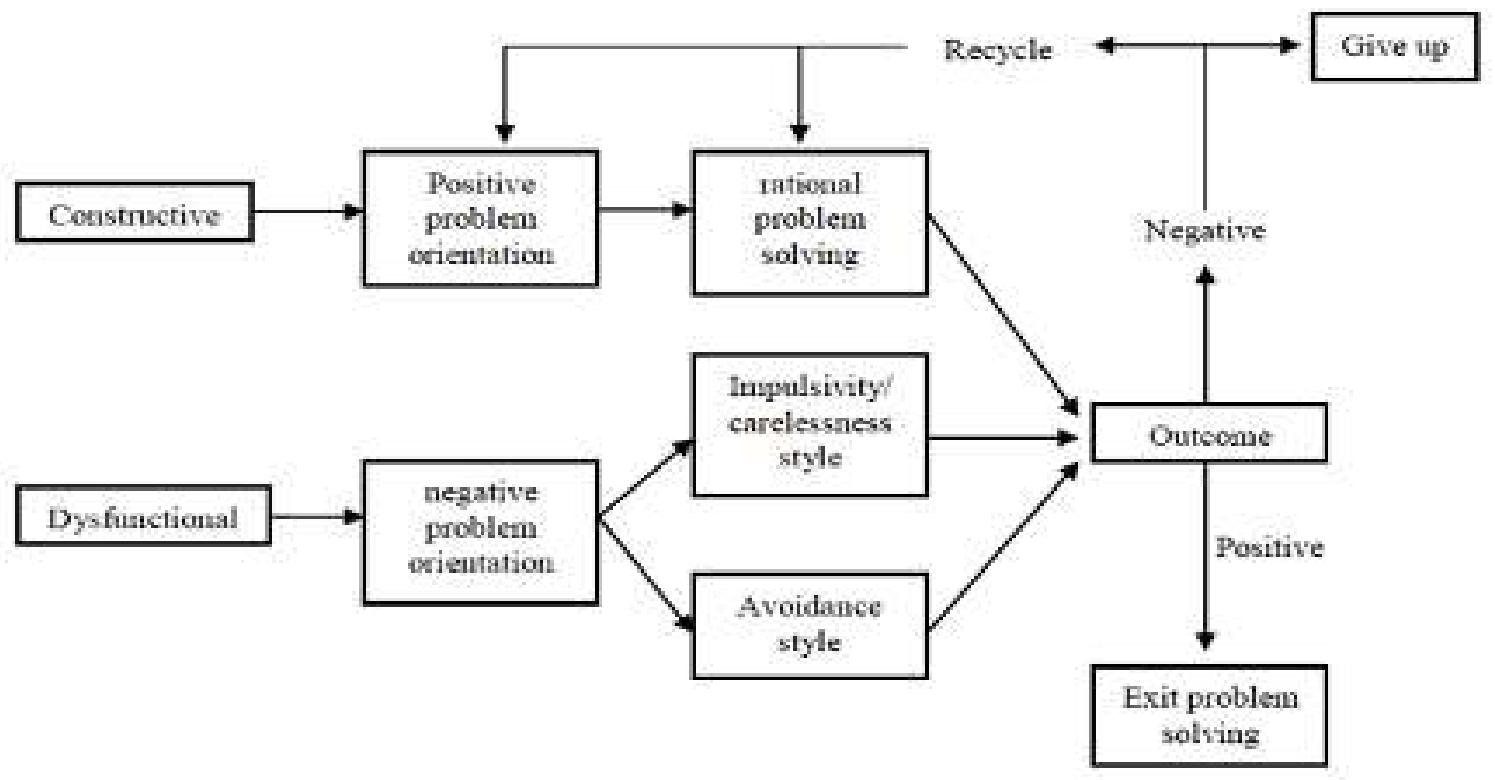

Fig. 1 Schematic representation of the social problem-solving process based on the five-dimensional model

More specifically, this qualitative research uses a phenomenological approach that focuses on human subjective experience and how humans interpret their world (Moleong, 2014). As the objective of phenomenology, the subjective experience will be reduced into a description that explains the universal essence of the phenomenon (Creswell, 2014). That is, the essence of the phenomenon is obtained from the similarities that experienced by a group of individuals in their life.

Through the phenomenology approach allows researchers to seek the essence of how migrants implement the Karmaphala value in the problem-solving process by interacting and talking directly with migrants who live in Bali. The variations of how migrants implement the Karmaphala value in the problem-solving process are more of an additional finding.

Sources of data in this study are words, behaviors, and actions that come from three informants. Three informants were selected using a purposive sampling technique because researchers had determined the characteristics of the population that fit to study and looked for samples that matched these characteristics (Johnson \& Chirstensen, 2012). A purposive sampling technique was chosen with the consideration that the researchers wanted to examine the implementation of Karmaphala values for migrants in Bali in the process of problem-solving so that the search for informants who were the source of data focused on adult migrants living in Denpasar.

The collected data then analyzed individually. That is, the unit of analysis used in this study is an individual analysis unit, with the consideration that researchers want to get an overview related to the implementation of the value of Karmaphala to migrants in Bali in the process of problem-solving. The individual analysis unit, the main focus on data collection is on what happens to individuals in a situation and how individuals are affected by the situation (Patton, 2002). Similarities between informants will be the focus of the analysis as the universal essence of phenomenon (Creswell, 2014), whereas variations will be an additional finding in this study.

Another important step carried out by researchers before analysis is to organize data. Data obtained from each informant through in-depth interviews were then converted into transcripts and affixed the codes on the transcripts that had been made. Coding is intended to be able to organize and systematize data in a complete and detailed manner so that it can bring up an overview of the topic under study which then makes it easier for researchers to find meaning from the data obtained.

Furthermore, the data analyzed using three steps proposed by Miles and Huberman, where the stages of data analysis are carried out interactively and continuously during the data collection process (Miles \& Huberman, 1984). The first step is data reduction with the aim of choosing the main things, focusing on the important things, then looking for themes and patterns. The reduction process is aided by electronic equipment such as laptop, to provide codes for certain aspects, so it is easier to get a clear picture of the application of Karmaphala values to Migrant communities in the process of solving problems. Display 
data can be done after the data reduction process. Data display is done to make a presentation to make it easier to understand what is happening and plan the next step based on what has been understood. Data display is carried out in the form of brief descriptions, charts, relationships between categories, flowcharts, and the like.

The last step is drawing conclusions that are expected to answer the research questions and see the relevance between the existing theories and the reality obtained in the field, especially related to the application of the Karmaphala values in the problem-solving process by Migrant communities who became informants in this study. Withdrawal of conclusions in this study is done by grouping or defining categories of information from each informant who have similarities so that they can be united and link the information to social problem-solving theory (D'Zurilla et al., 2002). The results obtained in this study can be declared valid if there is no difference between what the researcher reported and what actually happened to the object under study (Sugiyono, 2014) so that the credibility of the results of this study was tested through member check techniques. According to Lincoln and Guba, member checks were conducted to match the understanding of researchers regarding the data obtained by summarizing, repeating, or paraphrasing the speech of the people being studied while looking at the honesty and interpretation of the informants (Daymon \& Holloway, 2008).

\section{Results}

Based on the interview process that has been carried out, each informant has a different perspective and solution to the problem at hand. Although the resolution of the problem is different, the problem-solving process for each informant contains the implementation of Karmaphala values.

\subsection{First Informant}

The first informant stated that when he encountered a problem with another person (as a victim), he came near to the person and then scolded the person. On the same day, he accidentally grazed other people (as an actor) and one of them came near and scolded him. At the time of the incident, he just kept quiet and took a breath and felt that was the Karmaphala from his previous action that was felt so quickly. Based on this, the first informant stated that the presence of Karmaphala can make him more calm, patient, and often self-reflection before talking to others. The process of implementing Karmaphala values in the first informant's problem-solving process can be seen in Fig. 2.

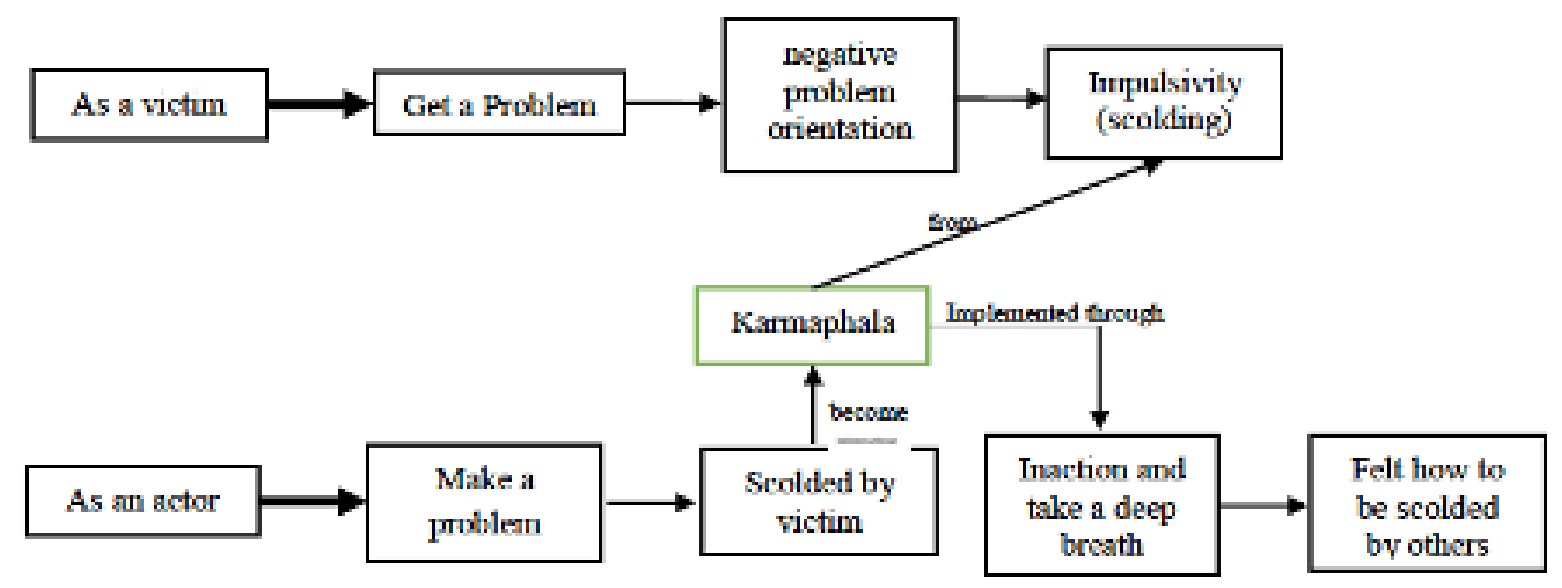

Fig. 2 Implementation process of Karmaphala value in First Informant's problem-solving

\subsection{Second Informant}

In contrast to the first informant, the second informant tends to repressed when he got some problems. He would become passive when he gets a problem due to his belief in Karmaphala's value that the 
problem makers will feel the equal consequences of their actions to him. The existence of the Karmaphala value reinforces him to become passive when he gets the problems. Furthermore, when he did not find a solution to the problem, the second informant only prays and surrenders because he believes that God could provide a solution to the problems at hand. Therefore, Karmaphala's value is implemented through praying and surrender to God. The implementation of Karmaphala value in the second informant's problem-solving process can be seen in Fig. 3.

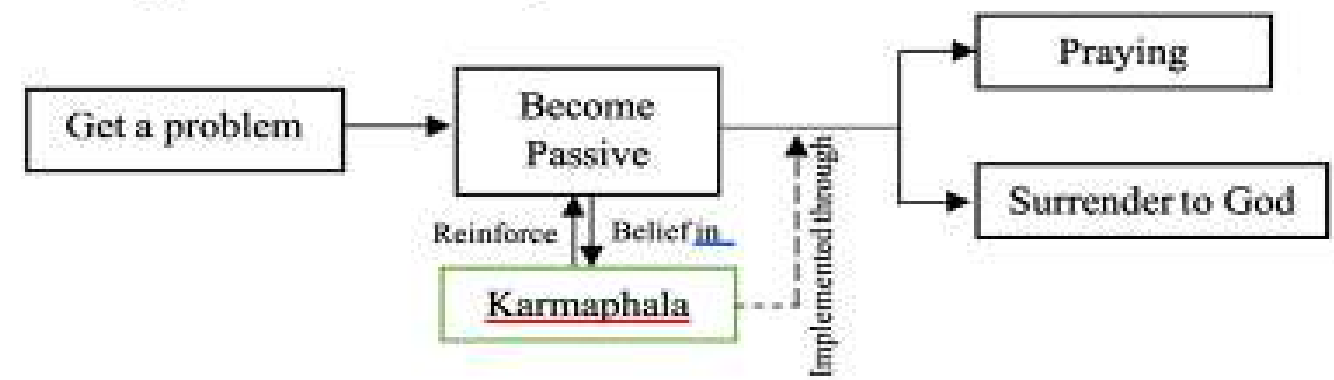

Fig. 3 The implementation process of Karmaphala value in Second Informant's problem-solving

\subsection{Third Informant}

Figure 4 shows that the Karmaphala values in the third informant was implemented in simple problems and not too detrimental to herself. As the third informant got a problem, she would classify the problem into two main groups, namely trivial or insignificant problems, and fatal or serious problems. If she got the trivial problems, she tends to do nothing like the way to solve them due to she believes in Karmaphala value that those trouble makers will get the same impacts of what they have been done to herself. Conversely, she will do something to solve the serious or fatal problems.

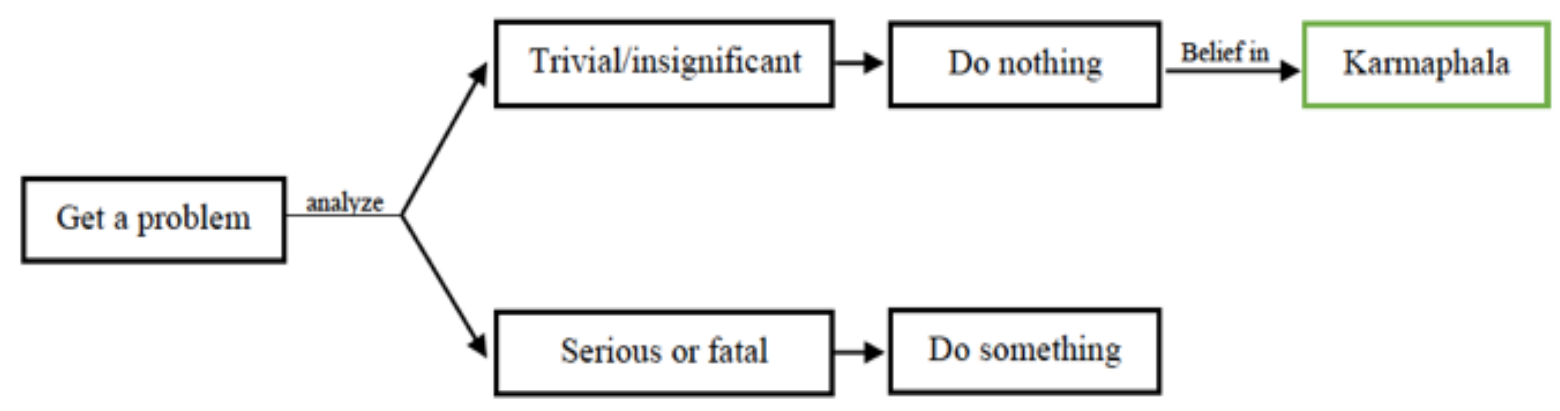

Fig. 4 Implementation process of Karmaphala value in Third Informant's problem solving

\section{Discussion}

The results of this study indicate that the implementation of Karmaphala is classified into avoidance problem-solving. This can be seen from the similarities of behavioral responses shown by all informants when facing problems. All informants become passive when facing problems due to a sense of trust in the value of Karmaphala. Passivity is one example of avoidance problem solving (D'Zurilla et al., 2002). Besides, the implementation of Karmaphala's values in problem-solving will lead migrants to think that the problems experienced will be felt by the problem makers and when the problem makers have felt the consequences of their actions, the informant tends to feel fair and the problem is considered over.

In some literature on problem-solving, problems are grouped into routine problems and non-routine problems. Routine problems are problems that are so familiar to the problem solver and know how to solve those problems, whereas non-routine problems are so unfamiliar to the problem solver that the 
problem solver does not know a solution method (Mayer, 2013). If related to the problem categories, the problems experienced by migrants may be classified as nonroutine problems due to the problem are so unfamiliar and as a consequence, migrants do not know how to solve them. This condition may trigger migrants to become passive, in addition to the existence of migrant knowledge of the concepts and beliefs about Karmaphala that can make the trouble maker get the consequences (Mayer, 1992, 2013).

The results also showed that the behavior shown by each informant in dealing with the problem is different from one another, although both were classified as avoidance styles. The first informant showed silent behavior and took a deep breath when facing problems, while the second informant prayed and surrendered to God when faced with problems. Similar to the first informant, the third informant tends to do nothing because she believes that the problem currently accepted will also be felt by the problem maker.

If related to the learning process, the problem is identical to the aversive stimulus. The problem is one example of aversive stimulus because there are some obstacles such as novelty, ambiguity, unpredictability, conflicting stimulus demands, performance skill deficits, or lack of resources (D'Zurilla et al., 2002). The existence of these obstacles can make the problem into something that is avoided and may be categorized as an aversive stimulus. The existence of the aversive stimulus experienced, organisms can use avoidance response as one way to face the aversive stimulus (Ormrod, 2003). The response to aversive stimulus comes in two forms, passive avoidance, and active avoidance. Passive avoidance is the absence of responses raised by an organism when facing an aversive stimulus, while when an organism shows a certain response actively to avoid an aversive stimulus is called active avoidance. Responses are done by each informant is classified as passive avoidance because there is no response made by the organism in the process of solving the problem. However, active avoidance also appears, especially in the third informant, such as report to the authorities when she experienced serious problems.

\section{Conclusion}

The implementation of Karmaphala value is more precisely associated with solving problems. This can happen because when the informants experienced a problem or get a reward from a bad thing that has been done before, the informant already knows that the things obtained at this time are a result of previous behavior. Moreover, the results obtained at this time will also be felt by the problem maker in the future. This then underlies the informants tend to be silent, praying, or surrender, because of the Karmaphala concept that applies. That is, those implementations of Karmaphala are the example of passive avoidance used by migrant to solve the problem.

Further development is needed as suggestions in future research, especially regarding the implementation of the value of Karmaphala in the process of solving problems for migrants. Development that can be done in the form of increasing the number of informants so that the results are more diverse and obtain new insights about Karmaphala from the perspective of migrants.

\section{References}

Bonner, H. (1953). Social Psychology: An Interdisiplinary Approach. Oxford: American Book.

Central Bureau of Statistic. (2015). Statistic of Migration Indonesia: Results of The 2015 Intercensal Population Survey.

Creswell, J. W. (2014). Research Design: Qualitative, Quantitative, And Mixed Methods Approaches (4th ed.). Los Angeles: SAGE Publications.

D’Zurilla, T. J., \& Goldfried, M. R. (1971). Problem Solving and Behavior Modification. Journal of Abnormal Psychology, 78(1), 107-126. Retrieved from https://doi.org/10.1037/h0031360

D’Zurilla, T. J., Nezu, A., \& Olivares, A. (2002). Social Problem Solving: Theory and Assessment. In E. C. Chang, T. J. D’Zurilla, \& L. . Sanna (Eds.), Social Problem Solving Theory, Research, and Training (pp. 
11-27). Research, and Training: Social Problem Solving Theory.

Daymon, C., \& Holloway, I. (2008). Metode-Metode Riset Kualitatif dalam Public Relations dan Marketing Communications. Yogyakarta: Bentang Pustaka.

Department of Labour and Transmigration of Bali Province. (2012). Labour Planning of Bali Province in 20122016.

Ghony, M., \& Almanshur, F. (2012). Metode Penelitian Kualitatif. Yogyakarta: Ar-Ruzz Media.

Johnson, B., \& Chirstensen, L. (2012). Educational Research: Quantitative, Qualitative and Mixes Approaches (4th ed.). Los Angeles: SAGE Publications.

Mayer, R. E. (1992). Thinking, Problem Solving, Cognition (2nd ed.). New York: W. H. Freeman.

Mayer, R. E. (2013). Problem Solving. New York: W. H. Freeman.

Miles, M., \& Huberman, A. (1984). Qualitative Data Analysis: A Source Book of New Methods. Los Angeles: SAGE Publications.

Moleong, L. J. (2014). Metode Penelitian Kualitatif. Bandung: PT Remaja Rosdakarya.

Munidewi, I. (2017). Akuntabilitas dalam Perspektif Ajaran Karma Phala sebagai Pedoman untuk Membangun Karakter Auditor. Jurnal Ilmiah Akuntansi Dan Bisnis, 12(2), 54-64. Retrieved from https://doi.org/10.24843/JIAB.2017.v12.i01.p07

Ormrod, J. E. (2003). Human Learning (4th ed.). Harlow: Prentice Hall.

Patton, M. (2002). Qualitative Research \& Evaluation Methods (3rd ed.). Los Angeles: SAGE Publications.

Sarwono, S. (2005). Psikologi Sosial: Psikologi Kelompok dan Psikologi Terapan. Jakarta: Balai Pustaka.

Sugiyono. (2014). Metode Penelitian Pendidikan (Pendekatan Kuantitatif, Kualitatif, dan R \& D). Bandung: Alfabeta. 